INTERNATIONAL JOURNAL OF SYSTEMATIC BACTERIOLOGY

Vol. 20, No. 3 July 1970

pp. $297-300$

Copyright 1970, Iowa State University Press

\title{
REPORT OF THE INTERNATIONAL COMMITTEE ON NOMENCIAATURE OF BACTERIA TAXONOMIC SUBCOMMITTEE FOR GRAM-NEGATIVE ANAEROBIC RODS
}

The Subcommittee was authorized at the International Association of Microbiological Societies (LAMS) meeting in Moscow, 1966.

Membership: The members of the Subcommittee are:

Beerens, Dr. H. (Chairman) Institut Pasteur, 20 Boulevard XIV, Lille, France.

Moore, Prof. W.E. C. (Secretary), Virginia Polytechnic Institute, Anaerobe Laboratory, Blacksburg, Virginia, U.S.A.

Barnes, Dr. Ella M., Food Research Institute, Colney Lane, Norwich, NOR 70F, England.

Bittner, Dr. J., Service des Anaérobes, Institut Dr. I. Cantacuzino, Spl. Independentei 103, Bucharest, Rumania.

Bryant, Prof. M. P., Dairy Science Dept., University of Illinois, Urbana, Illinois 61803, U.S.A.

Fievez, Dr. L., Ecole de Médecine Vétérinaire, 45 Rue des Vétérinaires, Bruxelles Cureghen, Belgium.

Finegold, Dr. S. M., Wadsworth Veterans Administration Hospital, Wilshire and Sawtelle Blvds., Los Angeles 90073, California, U.S.A.

Goldberg, Prof. H.S., School of Medicine; University of Missouri, Columbia, Mo., 65201, U.S.A.

Heineman, Dr. H.S., Dept. of Medicine, University of Pitts burgh, Pittsburgh, Pennsylvania, U.S. A.

Reinhold, Dr. L., Institut für Medizinische Mikrobiologie und Epidemiologie, Leninallee 6, 402 Halle (Saale) German Democratic Republic. Sonnenwirth, Dr. A.C., The Jewish Hospital, 216 S. Kingshighway, St. Louis, Missouri 63111 , U.S.A.

Suzuki, Dr. S., Gifu University, School of Medicine Tsukasa-Machi, Gifu-Shi, Gifu-Ken, Japan.

Werner, Dr. H. , Institut für Medizinische Mikrobiologie und Immunologie, 53 Bonn-Venusberg, Germany.

The first meeting was held in Lille, France, July 11-13, 1967, those present being H. Beerens (Chairman), W. E. C. Moore (Secretary), Ella M. Barnes, M. P. Bryant, L. Fievez, S. M. Finegold, H.S. Goldberg, A. C. Sonnenwirth, S. Suzuki and H. Werner. Prof. Lillian Holdeman (Virginia Polytechnic Institute) was present by invitation.

The second meeting was held in London, England, October 20-21, 1969, those present being $\mathrm{H}$. Beerens (Chairman), Ella M. Barnes, L. Fievez, S. M. Finegold, H.S. Goldberg, L. Reinhold, A. C. Sonnenwirth and H. Werner. In the absence of Dr. Moore, Dr. Barnes acted as Secretary. The following is a summary of the proceedings of both meetings and a report of the activities of the Subcommittee.

Prior to the first meeting, members of the Subcommittee exchanged strains which they considered to be of taxonomic importance and then studied these organisms using their own individual methods. The results 
obtained, together with those from other investigations, formed the basis of the decisions reached by the members of the Subcommittee at the Lille meeting. At this meeting the Subcommittee reviewed all the species of anaerobic Gram-negative rods listed in Prévot, Turpin and Kaiser (1967) and divided these into three categories, a) Species to be retained, b) Species requiring further study, and $\mathrm{c}$ ) Species to be discarded. This formed the basis of further work to be carried out by the Subcommittee. It was also generally agreed that there was no valid basis for a separation of the genera Fusobacterium and Sphaerophorus and it was recommended that the Sphaerophorus strains should be included in the genus Fusobacterium. The genus Bacteroides was retained as a separate entity, the main differentiating character being the production of butyric acid by all strains of Fusobacterium.

At their second meeting in London, the members of the Subcommittee dealt specifically with certain species.

Bacteroides fragilis and related organisms

The Subcommittee agreed to accept NCTC 9343 as the neotype strain of B. fragilis. It also agreed that in addition to B. fragilis, B. vulgatus, B. thetaiotamicron and B. distasonis are defined entities for which representative strains are available, the characteristics of which agree with the original descriptions of Eggerth and Gagnon (1933). B. vulgatus " ATCC 8482 and $B$. distasonis ATCC 8503 were accepted by the Subcommittee as representative strains. No decision was reached regarding a representative strain of $\mathrm{B}$. thetaiotamicron. The differentiation of these entities is based on biochemical properties and further supported by serological studies and evidence of pathogenicity (Sonnenwirth 1960; Reinhold 1964; Werner 1967; Werner and Reichertz 1969; and also Reinhold unpublished data). It should be noted that the serological differentiation of B. vulgatus and B. distasonis is based on the study of only a limited number of strains (Werner and Reichertz 1969).

The Subcommiteee agreed that B. convexus (Eggerth and Gagnon 1933), Ristella pseudoinsolita (Beerens and Aladame 1949) and Spha'erophorus intermedius (Bergan and Hovig 1968) are later and therefore illegitimate synonyms of B. fragilis (Veillon'and Zuber 1898) Castellani and Chalmers (1919) (Wernèr $\overline{1969 a, b}, c)$.

\section{Bacteroides melaninogenicus}

It was a consensus of the Subcommittee that the strains at present designated $\mathrm{B}$. melaninogenicus comprise a very heterogenous group of organisms which may be unrelated to each other. Fundamental differences exist between strains such as varying-capabilities for proteolysis and for carbohydrate fermentation, requirements for various growth factors, production of various dehydrogenases, $\mathrm{G}+\mathrm{C}$ ratios and whether or not butyric acid is produced. This coupled with a lack of information on whether or not one or more types of pigment is produced and whether or not some of the organisms so.classified may actually be cocci rather than bacilli indicate the urgent need for much additional work and the futility in the present state of our knowledge of attempting to arrive at a satisfactory definition or classification scheme. 
Bacteroides hypermegas (Harrison and Hansen, 1963).

The description of this new species was based on four strains, none of which survived. The Subcommittee was of the opinion that the 'group 4 ' poultry strains described by Goldberg, Barnes and Charles (1964) and Barnes and Impey (1968) belong to the same species although differing in certain details from the original description of Harrison and Hansen (1963). Reference strains of these organisms designated EBF 61/42, EBF 58/74 and EBF $61 / 61$ are in the National Collection of Type Cultures, London, under the numbers NCTC 10570, NCTC 10571 and NCTC 10572 , respectively. It was suggested that NCTC 10570 should be considered as the neotype strain for the species.

Bacteroides corrodens.

The Subcommittee agreed that further work is necessary to decide whether the microaerophilic and obligately anaerobic strains included under the designation Bacteroides corrodens belong to the same or different groups or species.

The Subcommittee expressed its thanks to Dr. Beerens for organising the Lille meeting and to Dr. Barnes for organising the London meeting.

- H. Beerens Chairman

\section{LITERATURE CITED}

Barnes, E. M. and C.S. Impey. 1968. Anaerobic Gram-negative nonsporing bacteria from the caeca of poultry. J. appl, Bact. 31:530541.

Beerens, H. and N. Aladame. 1949. Sur une nouvelle bactérie anaérobie Ristella pseudo-insolita nov. sp. Ann. Inst. Pasteur, Paris 76:476478 .

Bergan, T. and B. Hovig. 1968. A new species, Sphaerophorus intermedius, isolated from empyema. Acta path. Microbiol. Scand. 74: $\overline{421-430}$.

Castellani, A. and A. Chalmers. 1919. Manual of Tropical Medicine 3. Auflago; New York.

Eggerth, A.H. and B.H. Gagnon. 1933. The bacteroides of human faeces. J. Bact. 25:389-413.

Goldberg, H.S., E. M. Barnes and A. B. Charles. 1964. Unusual bacteroides-like organism. J. Bact. 87:737-742.

Harrison, A.P., Jr. and P. A. Hansen. 1963. Bacteroides hypermegas nov. spec. Antonie van Leeuwenhoek 29:22-28.

Prévot, A. R., A. Turpin and P. Kaiser. 1967. Les Bactéries Anaerobies, Paris, Dunod.

Reinhold, L. 1964. Stoffwechselleistungen bei Stännen des Genus Bacteroides. Zentbl. Bakt. ParasitKde (Abt. I), 193:491-501.

Sonnenwirth, A.C. 1960. A study of certain Gram-negative, nonsporulating anaerobic bacteria indigenous to man, with special reference to their classification by serological means. Dissertation, Washington Univ., St. Louis, 1960, Univ. Microfilms Publ. No. 60-4699. Dissertation Abstr. 21:1336. 
Veillon, M. M. and A. Zuber. 1898. Recherches sur quelques microbes strictement anaérobies et leur role en pathologie. Arch. Méd. Exp. 10:517-545.

Werner, H. 1967. Eggerthella-Arten aus pathologischem Material und aus Stuhlproben. Arch. Hyg. Bakt., 15:492-508.

- 1969a. Sphaerophorus intermedius Bergan and Hovig 1968, ein späteres und illegitimes Homonym von Bacteroides fragilis (Veillon und Zuber, 1898) Castellani und Chalmers 1919. Z entbl. Bakt. Parasitkde (Abt. I), 211:107-110.

- 1969b. Bacteroides convexus Eggerth und Gagnon 1933 identisch mit Bacteroides fragilis (Veillon und Zuber, 1898) Castellani und Chalmers 1919. ZentbI. Bakt. ParasitKde (Abt. I), 211:344-353. - 1969c. Vergleichende Untersuchungen an Stämmen von Ristella pseudoinsolita Beerens and Aladame 1949. Pathologie et Microbiologia

and C. Reichertz. 1969. Das serologische Verhalten von Stämmen der Species Bacteroides convexus, B. thetaiotamicron, B. vulgatus und $\underline{B}$. distasonis. Zentb1. Bakt. ParasitKde (Abt. I) $210 \overline{0}: 19 \overline{2-201 .}$ 